\title{
KAJIAN SEMIOTIK: INTERPRETASI PUISI KUROFUNE KARYA KINOSHITA MOKUTARO
}

\author{
Zaki Ainul Fadli ${ }^{*}$ \\ Program Studi Bahasa dan Sastra Jepang, Universitas Diponegoro, \\ Jl. Prof. Soedarto, SH, Kampus Undip Tembalang, Semarang, Indonesia 50275
}

\begin{abstract}
Abstrak
Artikel ini membahas mengenai interpetasi puisi dengan pendekatan semiotik. Sebagai objek kajian adalah salah satu puisi dari sastrawan Jepang Kinoshita Mokutaro yang berjudul Kurofune. Dalam membaca sebuah puisi, memecahkan kode-kode bahasa dan ungkapan konotatif yang terdapat dalam puisi dapat bermanfaat untuk memahami puisi tersebut. Sajak dalam Kurofune akan dianalisis dengan pendekatan semiotik dengan menggunakan teori dari Riffataere. Dalam teorinya, Riffataere mengungkapkan bahwa makna sebuah puisi dapat lebih dipahami dengan pembacaan secara heuristik dan hermeneutik. Dengan pembacaan tersebut, dapat ditemukan makna yang tersirat dari sajak-sajak dalam sebuah puisi. Kata kurofune biasanya digunakan untuk menyebut kedatangan kapal perang Amerika yang dipimpin oleh Komodor Perry yang tiba di Uraga, Jepang pada 1853. Akan tetapi, dari analisis dapat diketahui bahwa kata kurofune dapat pula dimaknai sebagai berakhirnya politik shakoku, yaitu politik isolasi dan dimulainya era baru bagi Jepang yang dinamai dengan Restorasi Meiji.
\end{abstract}

Kata kunci:pendekatan semiotik; puisi; kurofune

\begin{abstract}
[The interpretation of Kinoshita Mokutaro's Kurofune] This article discusses about the interpretation of poetry with semiotic approach. As the object of this study is one of Kinoshita Mokutaro's poetries: Kurofune. Decoding the dramatic situation and connotation of a poetic text can be helpful for its interpretation. The dramatic situation of Kurofune will be discussed with semiothics theory from Riffaterre. In Riffaterre's theory, poetry can be interpreted with heuristic and hermeneutic's reading. The purpose of this article is to know the poetry's implied meaning. The terms of Black Ships(Kurofune) commonly refer to the American steam-powered warships led by Commodore Matthew Calbraith Perry which first arrived in Uraga in 1853. But as the result of the analysis, the term kurofune can be also read as the end of shakoku and the beginning of new era called the Meiji Restoration.
\end{abstract}

Keywords:semiotic approach; poetry; kurofune

\section{Pendahuluan}

Puisi adalah genre sastra yang memiliki karakteristik unik karena di dalamnya sering terdapat kata-kata konotatif dan kalimat yang cenderung mampat.

Kurofune adalah salah satu puisi sastrawan Jepang yang mempunyai nama pena Kinoshita Mokutaro. Mokutaro lahir di prefektur Shizuoka Jepang pada 1 Agustus 1885. Nama aslinya adalah Tada Masao ( 太 田正雄). Mokutaro adalah seorang penyair, pemain drama, dan sering berkontribusi

${ }^{*}$ Penulis Korespondensi.

E-mail: zaki.undip@gmail.com dalam studi mengenai agama Kristen dan sejarah kesenian. Dia juga seorang profesor di Universitas Tokyo.

Kurofune (Black Ships) adalah sebutan populer untuk menyebutkan kedatangan bangsa Eropa pada abad 16 dan 19. Akan tetapi, terkadang dalam sebuah puisi tidak selalu kata-kata dimaknai secara denotatif. Dengan kata lain, puisi mengatakan satu hal dan memaksudkan untuk hal yang lain ( $a$ poem says one thing and means another). Oleh karena itu, artikel ini berusaha untuk menemukan makna yang tersirat dari puisi Kurofune. 
Dalam artikel ini, konsep semiotik akan digunakan untuk menemukan makna yang terkandung dalam puisi Kurofune. Ratna (2004) menyatakan bahwa sastra dalam bentuk karya atau naskah mengandung makna tanda-tanda, sesuatu yang lain yang diwalikinya, sebagai tanda-tanda nonverbal. Makna tanda-tanda bukanlah milik dirinya sendiri, tetapi berasal dari konteks di mana ia diciptakan, di mana ia tertanam (Ratna, 2004: 117). Tanda ini dikirimkan oleh pengirim (sender), yang bisa juga berarti penulis, kepada penerima (receiver), yaitu pembaca. Oleh sebab itu, pemahaman suatu karya sastra tidak bisa dilepaskan dari kenyataan di luarnya, yaitu masyarakat di mana karya itu hadir.

\section{Metode Penelitian}

Pendekatan yang digunakan dalam penelitian ini adalah pendekatan semiotik. Hal itu dilakukan mengingat semiotik merupakan suatu pendekatan yang menekankan pada aspek penggalian makna terhadap tanda dalam suatu karya sastra. Endraswara menyebutkan bahwa tanda sekecil apa pun dalam pandangan semiotik tetap diperhatikan (2003: 64).

Pendekatan semiotik yang akan dipakai adalah semiotik model Michael Riffaterre. Pendekatan semiotik model Riffaterre dipakai berdasarkan pertimbangan bahwa semiotik Riffaterre lebih mengkhususkan pada analisis puisi. Riffaterre dalam bukunya Semiotics of Poetry (1978) mengemukakan empat hal pokok sebagai langkah pemerolehan makna, yaitu analisis ketidaklangsungan ekspresi, pembacaan heuristik dan hermeneutik, penentuan matriks dan model dan analisis interteksualitas. Tidak semua konsep dan teori yang digunakan Riffaterre di atas akan digunakan untuk memaknai puisi Kurofune secara semiotik, tetapi hanya dua langkah pertama, yaitu analisis ketidaklangsungan ekspresi dan pembacaan heuristik dan hermeneutik.
Dalam puisi, ketidaklangsungan ekspresi menduduki posisi yang utama. Ketidaklangsungan ekspresi yang dimaksud disebabkan oleh adanya penggantian arti (displacing of meaning), penyimpangan arti (distorting of meaning), dan penciptaan arti (creating of meaning). Riffaterre (1978: 2) menyatakan bahwa penggantian arti disebabkan oleh penggunaan metafora dan metonimi, serta bahasa kiasan yang lain. Penyimpangan arti disebabkan oleh tiga hal, yaitu ambiguitas (ketaksaan), kontradiksi, dan nonsens. Sedangkan penciptaan arti diciptakan melalui enjambement, homologue, dan tipografi.

Hal kedua adalah pembacaan heuristik dan pembacaan hermeneutik. Pembacaan heuristik adalah pembacaan pada taraf mimesis atau pembacaan yang didasarkan konvensi bahasa. Karena bahasa memiliki arti referensial, pembaca harus memiliki kompetensi linguistik agar dapat menangkap arti (meaning). Kompetensi linguistik yang dimiliki oleh pembaca itu berfungsi sebagai sarana untuk memahami beberapa hal yang disebut sebagai ungramatikal (ketidakgramatikalan teks). Pembacaan ini juga disebut dengan pembacaan semiotik pada tataran pertama. Dalam pembacaan pada tataran ini, masih banyak arti yang beraneka ragam, makna yang tidak utuh, dan ketakgramatikalan. Untuk itu, pembacaan pada tataran ini masih perlu dilanjutkan ke pembacaan tahap kedua. Pembacaan tataran kedua yang dimaksud adalah pembacaan hermeneutik. Pada pembacaan ini, akan terlihat hal-hal yang semula tidak gramatikal menjadi himpunan kata-kata yang ekuivalen (Riffaterre, 1978: 5-6).

\section{Pembahasan}

Penyair ingin mencurahkan perasaan dan isi pikirannya dengan setepat-tepatnya seperti yang dialami hatinya. Selain itu, ia ingin mengekspresikannya dengan ekspresi yang dapat menjelmakan pengalaman jiwanya. Untuk itulah harus dipilih kata-kata yang setepat-tepatnya. Penyair juga ingin mempertimbangkan perbedaan arti yang sekecil-kecilnya dengan cermat. Penyair 
harus cermat memilih kata-kata karena katakata yang ditulis harus dipertimbangkan maknanya, kompisisi bunyi, dalam rima dan irama serta kedudukan kata itu di tengah konteks kata lainnya, dan kedudukan kata dalam keseluruhan puisi itu. Selain itu penyair juga mempertimbangkan urutan katanya dan kekuatan daya magis kata-kata diberi makna baru dan yang tidak bermakna diberi makna menurut kehendak penyair. Karena begitu pentingnya kata-kata dalam puisi, maka bunyi kata juga dipertimbangkan secara cermat dalam pemilihannya (Waluyo, 1991:72).

Berikut adalah puisi Kurofune karya Kinoshita Mokutaro.

\section{黒船}

1 人も来よ、異船くる、

2 いとくろく、烏に似たる。

3 あら笑止、船なる人も

4 皆黒し、帽も袷も。

5 このあまき葡萄の島に、

6 無花果の歓げる丘に、

7 何見ると千里鏡見る。

8 懷疑の北国人は。

\section{Kapal Hitam}

1 Orang-orang pun datang, kapal aneh datang

2 Bak gagak yang hitam legam

3 Oh menggelikan, kapal dan juga orangorang

4 Semuanya hitam, topi juga hakamanya

5 Menuju pulau penghasil anggur yang manis ini

6 Menuju bukit dimana buah tin/ara ada

7 Apapun yang dilihat, mereka melihat dengan teropong

8 Orang-orang negeri utara yang skeptis

\section{1) Pemilihan Diksi}

Judul puisi di atas adalah kurofune

( 黒船) yang berarti “kapal hitam”. Terminologi ini diberikan untuk kapal dari negara-negara Barat yang datang ke Jepang pada abad ke-16 dan abad ke-19. Secara khusus, kurofune digunakan untuk menyebut ekspedisi Komodor Perry yang datang ke pelabuhan Uraga, Kanazawa pada 14 Juli 1853. Kata hitam menunjukkan warna hitam kapal dan uap berwarna hitam hasil pembakaran batubara sebagai penggerak kapal Amerika.

Kapal digunakan untuk menampung orang-orang yang pergi ke tujuan tertentu. Berkaitan dengan kedatangan Perry sebagai langkah membuka Jepang dari politik isolasi, Kurofune juga dijadikan sebagai simbol berakhirnya politik isolasi di Jepang. Oleh karena itu, kurofune bisa pula dimaknai sebagai restorasi Meiji yang membawa Jepang ke arah perubahan menuju era modernisasi yang industri sebagai pilarnya. Warna hitam yang keluar dari cerobong kapal dapat dimaknai sebagai asap hitam yang keluar dari cerobong-cerobong pabrik/industri.

Baris 1 dan 2

$$
\begin{aligned}
& 1 \text { 人も来よ、異船くる、 } \\
& 2 \text { いとくろく、烏に似たる。 }
\end{aligned}
$$

Dari saja di atas dapat dilihat adanya ketidakberlangsungan ekspresi yaitu adanya penggantian arti yang disebabkan pemakaian bahasa kiasan. Pada baris ke-2 terdapat pemakaian metafora dalam kalimat "itokuroku, karasu ni nitaru" (sangat hitam, mirip dengan gagak). Kalimat tersebut merujuk pada kalimat sebelumnya yaitu "hito mo kitaruyo, ayashibune ga kuru" (kapal yang aneh dan juga orang-orang datang). Dari dua kalimat tersebut ditemukan majas simile (perbandingan) bahwa kurofune dan orang-orang di dalamnya mirip dengan gagak karena sama-sama memiliki warna hitam legam.

Kata ayashibune atau kapal yang aneh menunjukkan pada terminologi kurofune yang telah terdapat dalam judul dan telah dibahas sebelumnya. Sedangkan kata karasu(烏) berarti burung gagak (corvus). Gagak termasuk binatang yang mempunyai kecerdasan yang luar biasa. Di dalam kepercayaan terhadap Buddha di Tibet, Dharmapala (pelindung dharma) Mahakala 
dapat berwujud sebagai gagak ketika turun ke bumi. Di dalam kamus bahasa Jepang disebutkan bahwa meskipun ada yang menganggap bahwa gagak adalah burung yang mengerikan karena suara dan warnanya yang hitam legam, tapi ada pula kepercayaan yang mempercayai bahwa gagak adalah pelayan dewa dan memiliki kepandaian yang luar biasa.

Dalam sajak di atas, terdapat upaya membandingkan baris 1 dengan baris 2 yaitu kapal beserta orang-orang di dalamnya dengan kalimat "hitam legam seperti gagak". Dalam pembahasan sebelumnya diketahui bahwa kurofune dapat dimaknai sebagai simbol berakhirnya politik shakoku atau politik isolasi dan era dimulainya restorasi Meiji. Sedangkan orang-orang yang berada di kapal tersebut diibaratkan mempunyai kecerdasan yang luar biasa seperti gagak yang membawa serta ide-ide perubahan dalam restorasi Meiji.

\section{Baris 3 dan 4}

3 あら笑止、船なる人も
4 皆黒し、帽も袴も。

Dalam kalimat di baris 3 dan 4, disebutkan bahwa mereka mengenakan topi dan hakama yang hitam. Dari sajak di atas dapat diketahui bahwa yang dimaksud dengan orang yang berada di kapal tersebut bukan orang asing/orang Barat, tetapi orang yang memakai hakama (袴) yang merupakan pakaian Jepang. Oleh karena itu, dapat disimpulkan bahwa orang yang berada di kapal kurofune tersebut adalah orang Jepang. Penyair merasa geli karena orang-orang tersebut mengenakan hakama tetapi datang membawa sesuatu dari Barat (kurofune).

\section{Baris 5 dan 6 \\ 5 このあまき葡萄の島に、 \\ 6 無花果の歓げる丘に、}

Pada sajak di baris 5 dan 6, disebutkan tentang budou (葡萄) atau buah anggur dan ichijiku (無花果) atau buah ara.
Anggur (vitis) adalah sejenis buah yang mempunyai rasa manis, berbentuk bulat kecil, dan berwarna hitam, hijau, biru tua, kuning, atau merah tua. Anggur bisa dimakan langsung atau dibuat menjadi minuman jus atau wine. Anggur adalah buah yang relatif mahal. Wine yang terbuat dari anggur adalah minuman yang merupakan simbol dari kemewahan. Oleh karena itu, pulau anggur manis dalam sajak di atas dapat dimaknai bahwa Jepang adalah negara yang berharga.

Menurut wikipedia, ichijiku adalah buah ara atau disebut juga buah tin. Pohon ara memiliki nama ilmiah Ficus Carica yang dapat tumbuh di berbagai kondisi. Di dalam Bible, disebutkan bahwa Adam dan Hawa menutupi tubuh mereka dengan daun ara setelah mereka memakan buah larangan (Kejadian 3:7). Dalam kesenian, daun ara digunakan sebagai cover untuk menutupi alat kelamin atau pose telanjang objek lukisan. Kemudian dalam ajaran Buddha, ada kepercayaan bahwa Buddha memperoleh pencerahan di bawah pohon bodhi, yaitu pohon ara suci yang besar.

Oleh karena itu, "ichijiku no furageru oka ni" dapat dimaknai bahwa Jepang adalah negara yang suci, yang memiliki tradisi dan norma yang diagungkan.

Berdasarkan hal di atas, sajak di baris ke-5 dan ke-6 yaitu "kono amaki budou no shima ni" dan "ichijiku no fugeru oka ni" adalah tujuan orang-orang di dalam kurofune, yaitu Jepang yang merupakan negara yang berharga, negara yang memiliki tradisi dan norma yang diagungkan.

\section{Baris ke-7 dan ke-8 \\ 7 何見ると千里鏡見る。 8 懐疑の北国人は。}

Pada baris ke-7, terdapat kata "tohomegane miru" yang artinya melihat dengan teropong. Teropong biasanya digunakan di kapal untuk melihat sesuatu yang jauh sebagai cara untuk mendapatkan informasi dari tempat yang jauh demi antisipasi dan keamanan. Teropong juga bisa dimaknai sebagai metode ilmu pengetahuan yang selalu meragukan sesuatu sebelum 
benar-benar diketahui sesuatu benar atau tidak.

Kata kaigi( 懐疑) memiliki makna yang serupa dengan utagai (疑い) yang menurut kamus Kokugo mempunyai makna sebagai berikut.

1 "hakkiri shinai koto ni tsuite, warui hou ni kangaeru koto" yang berarti memikirkan sesuatu yang buruk/jelek terhadap sesuatu yang belum diketahui secara pasti.

2 "hontou ka douka, ayashii to omou" yang berarti mempunyai pemikiran yang meragukan terhadap hal yang belum tentu kebenarannya.

Sedangkan 北国 (Kitaguni atau Hokkoku) bisa memiliki dua arti. Pertama untuk menyebutkan negara-negara di sebelah utara Jepang; dan yang kedua untuk menyebutkan daerah-daerah di sebelah utara di Jepang yang beriklim dingin ekstrim. Dari pembahasan sebelumnya diketahui bahwa mereka memakai hakama, karena itu dari sajak tersebut dapat dimaknai bahwa orangorang yang berada di kurofune berasal dari daerah sebelah utara Jepang, artinya apabila kalimat tersebut dianggap sebagai pars prototo, maka dapat berarti bahwa mereka adalah orang Jepang secara keseluruhan.

Berdasarkan pengertian di atas, baris ke-7 dan ke-8 bermakna bahwa orang-orang yang berada di kurofune selalu menggunakan teropong untuk melihat sesuatu yang jauh karena mereka memiliki sifat yang skeptis terhadap sesuatu. Hal ini juga mengindikasikan mereka punya sifat kehatihatian sekaligus curiga terhadap sesuatu yang belum diketahui kebenarannya..

\section{2) Pembacaan heuristik}

Dalam pembacaan heuristik, sajak dibaca berdasarkan struktur kebahasaannya. Untuk memperjelas arti, bilamana perlu diberi sisipan kata, atau sinonim katakatanya ditaruh dalam tanda kurung. Begitu juga, struktur kalimatnya disesuaikan dengan kalimat baku (berdasarkan tata bahasa normatif). Apabila diperlukan susunannya dibalik untuk memperjelas arti (Pradopo, 1995:136 )
Dalam membaca puisi bahasa Jepang, perlu diketahui terlebih dahulu subjek dari puisi ini. Dari pembacaan secara keseluruhan, maka dapat dipahami bahwa subjek dari puisi ini terdapat dalam bagian akhir dari puisi yaitu dalam kalimat 懐疑の北国人は(orangorang dari negeri utara yang skeptis). Dalam kalimat itu orang-orang dari negeri utara memakai topi dan hakama hitam dan datang dengan menggunakan kapal hitam menuju ke daerah penghasil anggur yang manis dan bukit yang ditumbuhi pohon ara. Penyair juga menganggap bahwa kedatangan mereka sangat menggelikan. Untuk lebih jelasnya terlihat dalam pembacaan secara heuristik sebagai berikut.

1 人も来よ、異船くる (異船がくる、人 もくるよ)

Kapal aneh datang, orang-orang juga datang

2 (その船が) いとくろく、鳥に似た る

Kapal itu terlihat hitam seperti hitamnya burung gagak

3 あら笑止、船なる人も

Menggelikan(bodoh) sekali, mereka datang kesini

4 皆黒し、帽も袴も

Mereka yang memakai topi dan hakama yang hitam

5 このあまき葡萄の島に、

Mereka menuju pulau penghasil anggur yang manis ini

6 無花果の歓げる丘に、

Mereka menuju ke bukit yang ditumbuhi pohon dan buah tin/ara ini

7 何見ると千里鏡（で）見る

Mereka melihat dengan teropong untuk melihat sesuatu yang jauh, apapun yang mereka lihat

8 懐疑の北国人は（その船に乗る人々 である)

Mereka adalah orang asing yang datang dari negeri-negeri utara, yang selalu melihat dengan curiga. 
3) Pembacaan hermeneutik

Pembacaan heuristik kemudian diulang kembali dengan bacaan retroaktif dan ditafsirkan secara hermeneutik berdasarkan konvensi sastra puisi, yaitu sistem semiotik tingkat kedua. Konvensi sastra yang memberikan makna itu diantaranya konvensi ketaklangsungan ekspresi sajak yang telah diungkapkan sebelumnya.

Dari pembahasan sebelumnya, dapat diketahui bahwa subjek dari puisi tersebut adalah 北国人 yang berarti orang dari belahan utara Jepang. Apabila pemilihan diksi 北国人 bisa dianggap adalah pemakaian pars prototo, maka kata tersebut dimaknai sebagai orang Jepang secara umum. Orang Jepang yang diibaratkan pandai seperti gagak dan datang dengan menumpang kapal hitam yang dapat dimaknai sebagai restorasi meiji yang mengarahkan Jepang ke arah era modernisasi dan industrialisasi. Berikut pembacaan heurmeneutik secara lengkap pada puisi Kurofune.

\section{Kapal Hitam}

Baris 1 dan 2

Orang-orang datang bersama ide perubahan yang ingin merubah Jepang ke arah modernisasi (restorasi Meiji). Mereka adalah orang-orang yang pintar.

\section{Baris 3 dan 4}

Orang-orang tersebut adalah orang Jepang juga, tetapi mereka datang bersama sesuatu yang asing sehingga terasa menggelikan bagi yang melihatnya.

\section{Baris 5 dan 6}

Mereka ingin melakukan suatu perubahan di Jepang, negara yang berharga, negara yang memiliki tradisi dan norma yang diagungkan. Baris 7 dan 8

Mereka adalah orang yang berilmu, yang selalu meragukan sesuatu sebelum benarbenar mengetahui kebenarannya.

\section{Simpulan}

Puisi biasanya terdiri dari kata-kata yang termasuk second order language system, karena itu dibutuhkan sebuah cara tertentu untuk memahaminya. Pembacaan heuristik dan hermeneutik dapat dimanfaatkan untuk menemukan makna yang tersembunyi dalam puisi.

Dalam menafisr puisi, dimungkinkan berbagai lapis tafsir yang bermuara dari pemakaian kata-kata yang konotatif dan bermakna ganda yang terdapat di dalamnya. Dalam studi semiotik, hal ini sah karena sifat puisi yang polyinterpretable.

Kurofune atau Black Ships adalah sebutan populer untuk menyebutkan kedatangan bangsa Eropa pada abad 16 dan 19. Puisi Kurofune karya Kinoshita Mokutaro dapat pula dimaknai sebagai berakhirnya politik shakoku, yaitu politik isolasi dan dimulainya era baru bagi Jepang yang dinamai dengan Restorasi Meiji 


\section{Daftar Pustaka}

Endraswara, Suwardi. 2003. Metodologi Penelitian Sastra. Yogyakarta: Pustaka Widyatama.

Pradopo, Rachmat Djoko. 1995. Beberapa Teori Sastra, Metode Kritik, dan Penerapannya. Yogyakarta: Pustaka Pelajar.

Ratna, Nyoman Kuta. 2004. Teori, Metode, dan Teknik Penelitian Sastra. Jogjakarta: Pustaka Pelajar.

Riffataere, Michael. 1978. Semiotics of Poetry. Bloomington: Indiana University Press.

\section{Daftar Laman}

https://ja.wikipedia.org/wiki/北国 https://ja.wikipedia.org/wiki/カラス https://ja.wikipedia.org/wiki/イチジク https://ja.wikipedia.org/wiki/葡萄 https://en.wikipedia.org/wiki/Black_Ships http://www.home.ix.netcom.com/ kyamazak /lit/_Jpoet/Kinoshita_Mokutaro.htm

\section{Kamus elektronik}

Kamus Kokugo (Casio Ex-word XD-D2800) 